\title{
Russian policy on assistance to the resettlement of compatriots against the background of international experience
}

\author{
Ekaterina V. Donets ${ }^{1}$, Olga S. Chudinovskikh ${ }^{2}$ \\ 1 Independent Researcher, Moscow, 105568, Russia \\ 2 Lomonosov Moscow State University, Moscow, 119991, Russia
}

Received 30 May 2020 • Accepted 8 July 2020 • Published 25 September 2020

Citation: Donets EV, Chudinovskikh OS (2020) Russian policy on assistance to the resettlement of compatriots against the background of international experience. Population and Economics 4(3): 1-32. https://doi.org/10.3897/ popecon.4.e54911

\begin{abstract}
The article is devoted to the assessment of the conceptual framework and results of the implementation of the State Program of assistance to voluntary resettlement to the Russian Federation of compatriots living abroad in the context of international practice. Programs aimed at returning compatriots are practiced by a number of states wishing to attract ethnically and culturally related migrants or restore historical justice in relation to certain ethno-confessional groups. Typically, they exist along with other immigration programs, providing repatriates with almost unfettered admission to the country. Since 2006, the only program in this field in Russia is the State Program of assistance to voluntary resettlement of compatriots. The originally formulated principles place it in a special position when compared with other repatriation programs. Based on the evaluation of the experience of the Russian program and international experience in the establishment and application of ethnic repatriation programs, it was concluded that in some cases the additional requirements for compatriots are hardly compatible with the main humanitarian task of a repatriation program, which affects its final effectiveness.
\end{abstract}

\section{Keywords}

citizenship, compatriots, ethnocultural commonality, migration, repatriation, resettlement

JEL codes: J18, F22, K37

\section{Introduction}

In the Russian Federation, despite the recognized urgent need for immigrants, only a single comprehensive immigration program has been in place until now. This is the State Pro- 
gram of assistance to voluntary resettlement to the Russian Federation of compatriots living abroad (hereinafter referred to as the State Program). According to a number of criteria, it can be attributed to special programes supporting repatriation as a type of immigration. Such programs, varying in scale, are being supported in many countries around the world. At the same time, successful programs are not common. Programs tend to be based on ideas of ethnocultural proximity to the titular people of the country of immigration and/or desire to restore historical justice to representatives of certain ethnocultural groups associated with the country of future residence. The state Program occupies a special place among repatriation programs. The purpose of this article is to assess the conceptual framework and results of the implementation of the Russian State Program in the context of international practice.

The most well-known and effective programs, the participants of which should be selected on an ethnocultural basis, are the programs that are or were in force and legally supported in Germany, Israel, Kazakhstan and a number of other countries, the positive or negative experience of which provides grounds to additional conclusions about Russia.

The paper analyzes the policies of Russia and a number of other countries on assistance to the resettlement of migrants with ethnocultural closeness or historical ties with the population of the host country. Based on the analysis of the legal and regulatory framework and available statistical data, the weakest sides of the state Program are shown as well as the reasons for its low effectiveness. A conclusion is made about internal contradictions of the State Program, the necessity of liberating it from the function of regulating skilled labour migration and giving it an exclusively repatriation character.

\section{State Program of assistance to voluntary resettlement of compatriots to the Russian Federation}

The State Program was approved by the Decree of the Russian President of 22.06.2006 № 637. One of the priorities of Russia's migration policy - attracting people who directly or indirectly have historical links to our country and ethnocultural closeness with its population -was enshrined in its title itself. Established from the very beginning, the principle of territorial distribution of future immigrants was to play a key role in addressing regional development problems. The main objectives of the Program were: to stimulate and organize the process of voluntary resettlement of compatriots for permanent residence in the Russian Federation; to promote socio-economic development of regions; to solve demographic problems, primarily in the territories of priority settlement (Decree of the President... 2012). From the outset, the target population of the Program received an expanded interpretation, including cultural and linguistic community as the main criterion.

Before the start of the State Program, after the collapse of the USSR, in the 1990s and to a lesser extent in the first half of the 2000s, return migration to Russia, the volumes of which were great, was of the nature of ethnic repatriation. Direct evidence is the ethnic composition of migrants of that period (Vishnevsky 2013), mainly of Russian origin or their descendants, with the proportion of Russians in almost all years (since 1992) being $85 \%$ or more (except $2003-80 \%$ ). Post-Soviet immigration was largely of a forced nature. As the flow weakened by the mid-2000s, the need to 
create a new impulse to sustain it, using a Program encouraging voluntary resettlement, became apparent.

One of the main goals outlined in the State Program was to solve the demographic problem (compensation for the natural population loss), but in the context of the Program, the socio-economic considerations were apparent. The State Program (section IV) assumed the decision of potential immigrants to move on the basis of informed choice of place of residence and work (Rossiyskaya Gazeta 2006) (in a more recent revision - also places of study). At the same time, the scope of state guarantees and social support differentiated depending on the territory of settlement. In the first years only 12 regions of Russia participated in the State Program. Over time, the number of territories has changed and has now reached 76 (as of January 1, 2020) (MIA of Russia 2019a), but preferential settlement of eastern depressed regions in dire need of labour has been an unchanging direction for a long time. Thus, from the very beginning of the Program the first restriction manifested itself - conditionally free choice of place of residence.

Since its launch, the State Program has undergone notable changes in terms of expanding the list of regions and opportunities for participation of different categories of migrants. Amendments were repeatedly made to the conditions for the acquisition of Russian citizenship by immigrants. However, until recently it was true that the majority of migrants in the current period seek citizenship through the State Program, since only it has relatively clear rules for admitting foreigners to Russia for residence and accelerated citizenship (Denisenko \& Chudinovskikh 2017).

Since the establishment of the State Program, over 899 thousand people were able to move to their historical homeland (data of the Federal migration service (FMS) of Russia and the Main Directorate for Migration Issues (MDMI) of the Ministry of Internal Affairs of Russia, form 1-RD). After the rapid growth in the number of new participants during the Ukrainian crisis in recent years, the flow of new immigrants does not exceed 110 thousand people per year (MIA of Russia 2019c; 2020b). This represents less than half of the net migration required to maintain the current size of the population of Russia (the required estimate is 300 to 304 thousand migrants per year (Yumaguzin \& Vinnik 2019).

Thus, taking into account the role actually assigned to the Program as the main channel of immigration, it can be noted that it has not yet fulfilled its tasks. The reasons include the problem of its administration. According to the special representative of the State Duma on issues of migration and citizenship K. Zatulin, regions sabotage the Program by determining the regional quota for resettlement. At the same time, they act according to their needs in the labour market, which actually turns the Program of voluntary resettlement into a Program of recruitment of labour resources by the regions (Kommersant 2019).

At the regional level, this fact also has direct evidence. In a number of regions, the resettlement Program for compatriots is a part of the labour force development programs. Thus, in the Magadan Oblast, the Program of assistance to voluntary resettlement of compatriots is officially recognized as a subprogram of the State Program «Labour resources of the Magadan Oblast» (Resolution of Magadan Oblast... 2013), in the Republic of Sakha (Yakutia) it is the seventh subprogram of the State Program «Development of the labour market and promotion of employment of the population of the Republic of Sakha (Yakutia) for 2018-2022» (Decree of the Head of the Republic of Sakha... 2017). 


\section{Box 1}

The concept of repatriation is extensive in its content and does not yet have a single interpretation. Most often, there are differences in criteria of eligibility to participate in the process. But what remains unchanged is understanding repatriation as a process that implements the" personal right "of a participant to return to his or her country (under the conditions set out in international documents (IOM 2019)), that is in the modern sense is a country of citizenship, residence or origin. In the extended international interpretation, repatriation is the return to the country of nationality, permanent residence or origin of persons who are (due to different circumstances) on the territory of another state (Shurshalova 2019). Thus, not only emigrants themselves but also their descendants, may participate in the process. The definition takes into account the possibility of repatriation after the events that caused asylum seeking and/or emigration. This is the most common version of the interpretation in the analysis of repatriation, which has an ethnocultural basis.

Approaches developed with regard to the return of refugees remain applicable to repatriates, including: responsibility of the countries of origin to establish conditions for safe and decent return; the obligation of all states to agree to the return of their citizens; an appeal to all states to promote conditions facilitatinig the return of refugees and support their sustainable reintegration (Stein 1997).

However, the term «repatriation» in its original sense (as a return) has increasingly been applied conventionally. Both descendants of people who left the country earlier, and those who found themselves outside the country without moving anywhere, due to the border changes, become repatriates. Thus, ethnocultural identification most often becomes the condition of return. And the term «repatriation» is even proposed to be replaced by other terms, for example, resettlement or impatriation (this and other objections to the use of the term are considered by M. Kovalev on the example of the Polish repatriation (Kovalev 2009)). Since there is some common historical conditionality in all these cases, quite often, the process, including its current stage, is interpreted broadly as repatriation.

The effectiveness of the Program turned out to be different in certain periods, the Program clearly responded to external conditions. Thus, in the mid-2010s the current geopolitical situation contributed to the expansion of the contingent mainly at the expense of refugees from Ukraine. Forced migrants arriving en masse on the territory of Russia needed quick assistance. In order to resolve their status as soon as possible, a special procedure for processing applications for temporary asylum was introduced, and soon by the Decree of the President of Russia amendments were made to the conditions for admission to the State Program (Decree of the President... 2014). Individuals who were granted temporary asylum were able to immediately apply for participation in the State Program. This measure allowed tens of thousands of people to settle in Russia quickly and acquire citizenship in a simplified manner. This circumstance, rather than objective expansion of the State Program zone of influence together with increased interest in it from compatriots, were the main reasons for the sharp increase in its indicators in 2014-2015. The increased interest in the State Program since 2010 was also enforced to some extent: the conditions of access to Russian citizenship became more complicated forcing applicants to turn to other channels that gave an opportunity to quickly obtain Russian passport (Chudinovskikh 2014). 


\section{Legislative framework of the State Program}

The developed regulatory framework of the State Program is constantly being adjusted taking into account the emerging problems and circumstances. The main document governing the resettlement process, the State Program, has been repeatedly adjusted (18 times, the latest change was adopted in May 2020).

The main advantage of returnees over other categories of immigrants has been the provision of a number of preferences for moving and obtaining citizenship. Participants of the State Program were provided with compensation for several expenses, payments and benefits (see below in a separate paragraph). A compatriot who becomes a member of the State Program is issued a certificate. Upon expiry of the certificate, the compatriot and his or her family members lose their status: it is assumed that all problems of settlement in the country must be solved by that point. An increase in the term of validity of the certificate from three to five years means facilitation of the conditions of the migrants, giving additional time for documents processing (Decree of the President... 2020b). Participants are granted the right to obtain a temporary residence permit (TRP) beyond quotas, to obtain a permanent residence permit (PRP) and to acquire Russian citizenship in a simplified manner. An application can be submitted while being outside Russia, through foreign representations of the Ministry of Internal Affairs (and previously, the FMS of Russia).

Initially, the Program was limited to the period from 2007 to 2012, divided into three phases, but from December 31, 2012, the Program became unlimited. In 2012, the State Program was amended. The rights of participants and their family members during resettlement are defined, including the right to work as a paid employee, to receive professional education, to engage in investment, entrepreneurial and agricultural activities, agricultural production, to manage a personal subsidiary farm. Provision is made for compensation of the costs of visa registration, moving and transporting personal property to the place of registration at the place of stay. Amendments have been made to the provision on the procedure for consideration of issues of citizenship of Russia.

The two main directions of changes in the State Program were:

- clarification of the peculiarities of the territorial distribution of immigrants;

- specification of the target contingent of participants and the conditions for their participation in the Program.

\section{Territories of settlement}

The first version of the State Program assumed the possibility of resettlement to specific regions divided into three categories with different preferences for immigrants: A - predominantly strategically important border areas with declining population size; $\mathrm{B}$ - territories with positive socio-economic development dynamics, where major investment projects are being implemented, requiring widespread involvement of settlers due to the lack of labour supply in the territorial labour market and relatively low migration burden; $\mathrm{C}$ - territories with sustainable socio-economic development with a decline in total population and/or migration outflow.

At the end of 2012 (from 31 December) (Decree of the President... 2012) the division of regions changed: priority areas (initially included territories from group A) and other territories had been allocated. The first limitation was the reduction in 2013 of the list of strategically important border areas where the Program participants could expect the maximum volume of preferences. In accordance with the Decree of the President of the 
Russian Federation (Decree of the President... 2013), only compatriots who received a participant's certificate before 01.01.2013 and their family members were provided with the same amount of support for the period up to 01.01.2015 and under the same conditions that were valid until December 30, 2012. The list of territories since 2014 had been limited to 10 Russian regions. According to the latest adjustment (Decree of the President... 2019c), the areas of priority settlement since January 1, 2020 are all regions of the Far Eastern Federal District.

In 2018, the provision (paragraph 48) on the right of participants to make a voluntary choice of territory of settlement, taking into account the guarantees provided, social support and living conditions was excluded from the State Program. This provision has ceased to be in force since March 15, 2018. (Decree of the President... 2018a), the current document only mentions the voluntary participation in the State Program on the basis of informed choice of place of residence, work and/or study and implementation of potential labour, educational, creative and other opportunities on the territory of the Russian Federation (paragraph 13).

The improvement of the mechanisms of the State Program implementation included the adjustment of the conditions for voluntary resettlement of demanded specialists taking into account their expectations, as well as concentration of financial resources allocated to facilitate the resettlement in priority areas (Decree of the President... 2018b).

From March 28, 2019, participants of the State Program may allocate land plots in accordance with the Law on the «Far Eastern hectare» for free use, and when they receive Russian citizenship - as property (Federal... 2018a). It is possible to reregister the property rights for allocated plots. Persons who have built an individual dwelling house on the received hectare can apply for this before the expiration of the 5-year period from the date of granting the land for use.

Some of the regions that are particularly attractive to migrants have never taken part in the Program. In accordance with the last amendment to the State Program, regional resettlement programs of the Republic of Crimea, Moscow Oblast, the cities of Moscow, St. Petersburg and Sevastopol can be developed if there is a need for the economy of these regions in immigrants and the possibility of their reception and settlement (Decree of the President... 2020a).

Thus, throughout almost the entire period of the State Program operation, there were territorial restrictions for resettlement, both direct and indirect, reducing the possibilities of relatively comfortable voluntary resettlement.

\section{Program participants}

Who are the immigrants and what criteria are they required to comply with in order to get the right to participate in the State Program? In the original version, these are compatriots living abroad who can relocate with their family members. Currently, it can be both Russian compatriots living abroad and compatriots living legally on the territory of the Russian Federation, permanently or temporarily, or having temporary asylum in Russia. The last condition, as noted earlier, was introduced in the summer of 2014 during the beginning of the mass influx of forced migrants from Ukraine. Family members include spouses, children (in all cases, children adopted or being under guardianship have equal rights), children of spouses, participants' and their spouses' parents, siblings, children, grandparents and grandchildren. The State Program participants' family members account for about half of 
the annual flow of arrivals and the number of those registered at the end of the period. From July 1, 2020, without exception, all adult family members of a State Program participant can independently participate in the State Program (previously the participant's spouses did not have this right) (Decree of the President... 2020b).

The criteria for determining the target population - compatriots abroad, as well as the principles and objectives of the state policy regarding this category were elaborated even before the adoption of the first version of the State Program.

Compatriots are persons born in the same state, living or residing in it and possessing the characteristics of a common language, history, cultural heritage, traditions, and customs, as well as their descendants in a direct descending line. According to the criteria for being classified as compatriots abroad, they can be (Federal... 1999):

1. Russian citizens permanently residing outside the country;

2. persons and their descendants living outside the territory of Russia and belonging to the peoples historically living in the territory of the Russian Federation, as well as persons having made a free choice in favour of spiritual, cultural and legal relations with the Russian Federation whose relatives in direct ascending line previously lived in the territory of Russia, including:

a. former citizens of the USSR living in the states that were part of the USSR, who had obtained the citizenship of those states or became stateless;

b. natives (emigrants) from the Russian State, the Russian Republic, the RSFSR, the USSR and the Russian Federation who had the relevant citizenship and became citizens of a foreign state or stateless persons.

Thus, it is assumed that a compatriot must meet at least one of three criteria: citizenship (USSR, Russian Federation); ethnicity (indigenous peoples of Russia); territory (descendants of inhabitants of the territory of the Russian Federation). And this is exactly the approach used in the State Program.

In view of the above, the Program actually cannot be attributed to the group of purely ethnic repatriation programs, however, it includes generalizing features of programs that are successors to genuine repatriation programs.

Ethnic repatriation programs nevertheless took place in certain territories of Russia in the early 1990s. According to O. Vykhovanets and A. Zhuravsky, the most prominent example was Tatarstan. President of the Republic of Tatarstan M. Shaimiev appealed to the Tatars from CIS countries to return to their homeland. Several settlements for immigrants were set up for 100-150 houses, but not all immigrants received the promised aid and status giving hope for material support. The arrangement of settlements and the construction of houses were carried out at the expense of the FMS and local budgets and partly at the expense of returnees (Vykhovanets \& Zhuravsky 2013).

In a sense, the approach chosen in the State Program to determine the target group is logical for the state with an ethnically and confessionally heterogenous population. Under these conditions, according to A. Chesnokov, it is quite difficult "to give a semantic definition of the concept of a "compatriot", the state tries to avoid a rigid ethnic or confessional affiliations and makes the idea of a common history, a common culture and common language the integral core of the of 'compatriot"' (Chesnokov 2008). It was for this reason that earlier, in 2005, the concept of the Law "On repatriation to the Russian Federation" proposed by the Institute of CIS countries, which had an ethnic focus, did not find support in the State Duma. The main objectives were: the creation of prerequisites and guarantees for voluntary return of Russian compatriots born on the territory of present Russia and their ancestors to 
their historical homeland; preservation of the national (ethnic) core of Russia; prevention of assimilation of compatriots in post-Soviet states professing the idea of construction of mono-ethnic states (RIAC 2013).

The criteria outlined above were not the only condition of participation in the State Program in practice. Since the first years of the Program, additional requirements have been applied to participants, including: age - 18 years and older; legal capacity; compliance with the requirements established by federal and regional programs (MIA of Russia 2019b). Starting from May 31, 2019, requirements for compatriots must be officially specified in the regional resettlement program (Decree of the President... 2019a). One of the important conditions is the knowledge of Russian language (oral and written) at a level sufficient for quick adaptation, which meets the requirements for obtaining a TRP on the territory of the Russian Federation (for compatriots living abroad).

Although labour and other (educational, investment, entrepreneurial, etc.) activities are listed as the rights of participants in the State Program, in its descriptions available on other official websites these activities are already considered to be more like terms of admission to the Program. At the same time, participants of the State Program are considered, first of all, as persons "planning to relocate under a certain employment vacancy, intending to receive professional education in Russia, and compatriots who intend to create their own business, including in the agricultural sector, or simply to engage in personal subsidiary farming" (Rossotrudnichestvo 2019). In the first instruction on work with compatriots it was stated that the issuance of a certificate of a State Program participant occurs after receiving a questionnaire with information on the decision of the authorized executive authority of a Russian region on the admission and employment of a compatriot (Order... 2007).

The foregoing gives rise to conclusions that the Program has not become a repatriation program (Krasinets 2016) and that it is primarily a labour migration program. In practice, the regions also make additional demands for resettlers as skilled labour migrants. Thus, for example, selection criteria in the Vladimir Oblast include working age and a degree of higher education (Resolution... 2018). Some researchers even suggested applying a point system for selection of participants at the level of a separate region (Strusov and Yukhachyov 2016). In the ideas expressed by the authors of the cited article, the highest number of points are awarded on characteristics relating to work activity. It is also noteworthy that the criteria for compliance of a compatriot with the requirements of the regional subprogram may contain a demand to resettle together with the spouse, minor children (a similar criterion was contained in the first version of the program of the Republic of Sakha (Yakutia), the last version states that applications of such families are considered in priority order (Decree of the Head of the Republic of Sakha... 2019).

Unfortunately, in relation to the participants of the State Program, as well as many other categories of migrants in Russia, there is a large shortage of information. Virtually nothing is known about the composition of migrant families and their socio-demographic characteristics. We do not know how the lives and migratory trajectories of the resettlers have evolved, how many have left the regions of primary resettlement after obtaining citizenship, how integration of migrants in the a new place of residence and their entry to the labour market occurred, etc. These questions could be answered by a census or a large-scale sample survey (e.g. a labour force survey), if the survey program contained a question about whether the respondent was a participant in the State Pro- 
gram. Longitudinal specialized surveys of resettlers could shed light on the dynamics of the situation over time. Such projects are quite realistic, as the addresses of residence of the State Program participants are known and on this basis it would be possible to form a panel for carrying out similar sample surveys. We hope that such studies will be carried out.

\section{Assistance system}

State guarantees and social support measures, both at the federal and regional levels, are provided to participants and their family members. The list of measures and the amount of assistance throughout the period of operation of the State Program have always been differentiated depending on the territories of settlement.

In the first version of the State Program, state guarantees of three levels were offered depending on the territory of settlement (Order... 2006). In strategic areas of group A, state guarantees and social support were provided in full. When moving into group B the monthly allowance paid in the absence of income from work and other activities was excluded from the full package. When settling in the territory of group $\mathrm{C}$ the above-mentioned allowance and settling-in allowance were also excluded.

A set of modern state guarantees and measures of economic assistance are available to compatriots only until the expiration of the State Program participant certificate. It includes a number of positions (MIA of Russia 2019b), the content and comments to which are provided below:

1. Compensation of the cost of moving to a place of residence at the expense of the federal budget - actual cost of the consular fee, reimbursement of the visa fee and application for issuance of a TRP, moving and transfer of personal property to the place of registration at the place of stay (for foreign citizens), registration at the place of stay (for citizens of the Russian Federation) or registration at the place of residence of resettlers in the territory of settlement. For details on the payment procedure, see (Resolution ... 2007b).

2. Exemption from payment of customs in accordance with the legislation of the Customs Union. The terms are defined by the agreement between the governments of the Russian Federation, the Republic of Belarus, the Republic of Kazakhstan, the Republic of Armenia and the Kyrgyz Republic on the Eurasian Economic Union of May 29, 2014 (Treaty... 2014). Goods must be purchased before the date of relocation, and vehicles (not more than one car and one trailer) - at least 12 months before the date of relocation, import to Russia is possible in a term no later than 18 months from the date of arrival of the person for permanent residence (Part 6, Article 190 of the Federal Law on Customs Regulation (Federal... 2018b).

3. Compensation of expenses for payment of the state duty for registration of documents determining the legal status of immigrants on the territory of Russia, including for issuance of TRP, permanent residence permit, consideration of applications related to citizenship registration, issuance of a passport of a citizen of the Russian Federation (the procedure for payment of this type of compensation is determined by the decision of the Government of the Russian Federation (Resolution... 2008a)).

4. Provision of state support in the form of a settlement allowance. There are differences in the manner in which this type of support is provided, depending on the category of territory (Table 1). 
Table 1. The amount of allowances for arrangement in the territories of priority settlement.

\begin{tabular}{|c|c|c|c|c|}
\hline \multirow{3}{*}{ Payment dates } & \multicolumn{4}{|c|}{ Allowance amount } \\
\hline & \multicolumn{2}{|c|}{$\begin{array}{l}\text { to those coming from } \\
\text { abroad or other (not pri- } \\
\text { ority) region of Russia }\end{array}$} & \multicolumn{2}{|c|}{$\begin{array}{l}\text { to those temporarily } \\
\text { residing in the territory } \\
\text { of priority settlement }\end{array}$} \\
\hline & $\begin{array}{l}\text { to partici- } \\
\text { pants }\end{array}$ & $\begin{array}{l}\text { to family } \\
\text { members }\end{array}$ & $\begin{array}{l}\text { to partici- } \\
\text { pants }\end{array}$ & $\begin{array}{l}\text { to family } \\
\text { members }\end{array}$ \\
\hline $\begin{array}{l}\text { Immediately after arrival and registration } \\
\text { at the place of stay/place of residence, } \\
\text { thousand rubles }\end{array}$ & 150 & 70 & 50 & 25 \\
\hline $\begin{array}{l}\text { After expiration of } 18 \text { months from the } \\
\text { date of registration by place of residence } \\
\text { (registration by place of residence)/place } \\
\text { of residence, thousand rubles }\end{array}$ & 90 & 50 & 30 & 15 \\
\hline
\end{tabular}

Source: Compiled according to (Resolution... 2013).

In the territories not classified as priority, payments are made lump sum: to a participant -20 thousand rubles, to a family member -10 thousand rubles. Persons who arrived on the territory of Russia on an emergency basis, recognized as refugees or granted temporary asylum, who had become participants of the State Program, were paid an allowance in the amount stipulated for resettlers from abroad, also depending on the category of the territory of entry (Decree of the President... 2013).

In accordance with the Presidential Decree adopted in May 2020 (Decree of the President... 2020b), when determining the size of the settling-in allowance (construction allowance), the subsistence minimum for the main socio-demographic groups in the region will be taken into account in the future.

5) Obtaining a monthly allowance in the absence of income from labour, business and other (not prohibited by law) activities.

The benefit for participants and their family members is valid only in the territory of priority settlement (until the date of acquisition of citizenship, but not more than 6 months), its amount is $50 \%$ of the subsistence minimum in the Russian region (not paid to family members of a participant under the age of 18 and entitled to pension security) (Resolution... 2007a).

Participation in the State Program gives the right to receive TRP on a priority basis (without taking into account quota and without providing a document confirming knowledge of Russian language, the basics of legislation and history of the Russian Federation), permanent residence permit and citizenship of the Russian Federation (upon arrival in the Russian region, the participant of the State Program and members of his family must issue relevant documents (TRP, permanent residence permit) confirming the legality of their presence in the territory of the Russian Federation. During the period of validity of the TRP and in the presence of legal grounds, the State Program participant has the right to apply for a residence permit or for granting citizenship of the Russian Federation). The Federal Law "On citizenship of the Russian Federation" provides for the possibility of the Program participant and members of his or her family acquiring citizenship in a simplified manner if they have registration at the place of residence or are registered at the place 
of stay in the territory of the selected region (in particular, bypassing the stage of obtaining a residence permit in the Russian Federation and without observing the condition of a five-year continuous residence in the territory of Russia). The possibility of obtaining citizenship in a simplified manner is an incentive, perhaps the main one, to participate in the Program.

Members of the State Program and family members have the right to carry out labour activities in Russia without obtaining a work permit or a patent. The employer does not need permission to attract and exploit such foreign workers. For all participants of the State Program and members of their families, a preferential 13\% tax rate on income from work activity in the first six months of their residence in Russia (with the income of temporary labour non-resident migrants (under the law, dwelling and employed less than 183 days in the territory of Russia, i.e. just six months) are subject to a rate of $30 \%$, and for those holding patents the rate is fixed and depends on region of work). The state fee for registration at the place of residence has been deferred.

The solution of other complex issues of arrangement - provision of other state guarantees, social support, employment, provision of necessary housing - is the responsibility of regions, including through regional resettlement programs. For a long time the most vulnerable remained the possibility of obtaining housing even in those labor-deficient regions that are part of the priority settlement territories. By the Decree of the President of the Russian Federation of 05.12.2020 (to enter into force on July 1 of this year) (Decree of the President... 2020b) it is assumed only in the regions of priority settlement after obtaining citizenship to provide housing subsidies for the acquisition of housing, the amount of which is determined taking into account the indicators of the average market value one square meters of housing. At the same time, the period before obtaining citizenship will remain difficult. Most regions do not have a temporary housing fund. The provision of housing in some cases is associated only with specific vacancies from the databases.

Regional authorities provide social support, medical assistance, solution of education issues, employment, as well as support for small and medium-sized businesses, including the establishment of peasant (farm) households. Participants and family members should have access to almost all levels of education (from preschool to higher education, including additional professional), free medical care, places in social service institutions, employment promotion services, vocational guidance, employment, paid public works, job fairs, and training jobs, information about the situation on the labour market in the Russian region.

Thus, in fact, the main burden for the reception and arrangement of compatriots, both financial and organizational, rests with the Russian regions. In these conditions counter-reaction of regions in the form of making additional requirements for participants (age, professional) who have to justify their presence at of specific territory looks natural. Such an opportunity is enshrined in the State Program itself. In May 2019, an addition was made in the form of a subparagraph of paragraph 52, devoted to the content of regional resettlement programs. Now they must contain requirements for compatriots participating in the implementation of the Program (Decree of the President... 2019a). The description of vacancies and housing conditions offered to immigrants, which the regions published in the first years of implementation of the State Program, showed a clear unwillingness to accept compatriots. Often the level of salary even for specialists with higher education did not exceed the value of the subsistence wage and the supply of housing was absent (it was supposed to 
be hiring at the expense of the resettler). Dormitory beds or dilapidated housing that required repairs were offered. All this gave the impression that the regions were not interested in receiving migrants and did not seek to increase the attractiveness of the State Program "enforced from above". It is likely that the requirements to professions of participants of the State Program appeared as a reaction to its mandatory character. Regional authorities decided that if participation in the State Program is inevitable, then it is necessary to at least benefit from it, having established the appropriate conditions. The 2019 decree only cemented the established practice.

\section{Characteristics of the State Program implementation process}

Twelve regions became initial participants of the State Program - Krasnoyarsk, Primorsky and Khabarovsk Krai, Amur, Irkutsk, Kaliningrad, Kaluga, Lipetsk, Novosibirsk, Tambov, Tver and Tyumen Oblasts.

The first years of the Program fell short of expectations. According to expert estimates, the migration potential of the Russian-speaking population and titular peoples was significant. According to the data (2004) obtained 2 years before the start of the State Program, the number of persons who considered Russian as their native language in the countries of the post-Soviet space amounted to 26.4 million people, 63.6 million of which actively spoke Russian (Arefyev 2006). According to J. Zayonchkovskaya in 2006, migration potential of titular and other peoples of the CIS countries was up to 6-7 million people in the period up to 2025 (Zayonchkovskaya 2007), according to other estimates - about 3 to 4 million people (Ryazantsev and Grebenyuk 2008). However, instead of the planned inflow of 50 thousand people, in the first year of the Program, according to the Ministry of Internal Affairs of the Russian Federation, fewer than 700 participants and members of their families arrived in Russia and only to 9 out of 12 regions. About $60 \%$ of the inflow fell on the Kaliningrad Oblast.

At the launch of the State Program, the authorities (or the authors of the project) relied upon extremely optimistic predictions. The plans of the FMS of Russia for 2008-2010 estimated that the number of applicants and their families would be 87,000 in 2008; 115,000 in 2009 and 130,000 in 2010 (Report on results... 2007). Such forecasts, in our opinion, were political because by the time of writing the quoted paper, actual figures were already known, they were rather low.

The results of the first three years of operation of the State Program were almost unnoticeable against the background of the total flow of immigrants to Russia (the share of participants of the State Program in the total flow of migrants in 2009 was 1\%). Detailed data on the number of participants of the State Program is presented in Table 2.

The lack of demand for the State Program in the first years of its operation manifested itself both on the part of potential participants - compatriots, and on the part of regions that had to accept immigrants, attempts were made to explain low numbers of of participants of the State Program. Such reasons as a difficult economic situation and unpreparedness of regions, housing problem and connection to the pre-defined place of work and weak awareness of potential participants were also named. According to K. Romodanovsky (former head of the FMS), in 2007 fourteen regions refused to implement the Program of resettlement of compatriots. The regional authorities were not interested in participating in the Program from the beginning and wrote a waiver referring the high migration burden (Gazeta 2007). 
Table 2. Number of registered participants of the State Program and members of their families, 20072019, thousands of people.

\begin{tabular}{|c|c|c|c|c|c|c|c|c|c|c|c|c|c|}
\hline \multirow{2}{*}{ Categories } & 2007 & 2008 & 2009 & 2010 & 2011 & 2012 & 2013 & 2014 & 2015 & 2016 & 2017 & 2018 & 2019 \\
\hline & \multicolumn{13}{|c|}{ Applications accepted } \\
\hline $\begin{array}{l}\text { From the } \\
\text { participants } \\
\text { of the State } \\
\text { Program }\end{array}$ & 0.3 & 4.1 & 3.5 & 5.5 & 17.1 & 31.5 & 16.9 & 52.4 & 89.9 & 73.0 & 59.2 & 51.4 & 51.2 \\
\hline $\begin{array}{l}\text { From the } \\
\text { participants' } \\
\text { family } \\
\text { members }\end{array}$ & 0.4 & 4.7 & 4.0 & 5.4 & 12.4 & 25.4 & 17.8 & 53.9 & 93.3 & 73.6 & 59.4 & 56.3 & 57.3 \\
\hline \multirow[t]{2}{*}{ Total } & 0.7 & 8.9 & 7.5 & 10.8 & 29.5 & 56.9 & 34.7 & 106.3 & 183.1 & 146.6 & 118.6 & 107.7 & 108.5 \\
\hline & \multicolumn{13}{|c|}{ Stock at the end of the year } \\
\hline Participants & 0.3 & 4.1 & 7.5 & 12.9 & 30.7 & 61.8 & 78.2 & 130.2 & 218.4 & 289.8 & 347.5 & 396.9 & 445.9 \\
\hline $\begin{array}{l}\text { Family } \\
\text { members }\end{array}$ & 0.4 & 4.7 & 8.7 & 14.1 & 26.8 & 51.9 & 69.4 & 122.9 & 214.4 & 286.2 & 344.2 & 398.2 & 453.2 \\
\hline Total & 0.7 & 8.8 & 16.2 & 27.0 & 57.5 & 113.8 & 147.6 & 253.2 & 432.8 & 576.0 & 691.8 & 795.1 & 899.1 \\
\hline
\end{tabular}

Source: FMS/ MDMI of the Ministry of Internal Affairs of Russia, form 1-RD.

*Participants of the State Program remain on account regardless of acquisition of citizenship, deregistration takes place in case of voluntary refusal of participation, decision of territorial authority on migration issues on loss of status and death. According to the data of MDMI of the Ministry of Internal Affairs of Russia for 2014-2019, about 20 thousand participants of the State Program with family members were removed from the register, $68 \%$ of which voluntarily refused participation, $31 \%$ were deprived of participation status by decision of the territorial authority of the MDMI and $1 \%$ due to death (data from form 1-RD for the years indicated.)

The Accounts Chamber of the Russian Federation named one of the official versions: the main reason for the failure of the State Program in 2007-2008 was the fact that Russia "has not been able to create new FMS representative offices abroad because of the opposition of the authorities of the CIS members with the greatest migration potential" (Newsland 2009). Among such countries Kazakhstan, Moldova, Uzbekistan and Ukraine were named.

But we believe that circumstances of a different nature have also played a crucial role. The Law on Citizenship (Part 4 of Article 14), up to July 2009, provided wide access to citizenship of the Russian Federation for persons with temporary residence permits. In fact, most of those wishing to move to Russia used the usual channel of immigration - on the basis of obtaining a TRP, which also did not imply restrictions on the choice of the region of residence (for more information see (Chudinovskikh 2018)).

The number of participants (with family members) began to grow rapidly after 2009 . Organizers of the State Program explain this by the increase in the number of participating territories. In 2010 there were already 37 of them. At the same time, the claim that the main reason for the increase in the number of participants of the State Program is the absence of 
other transparent channels for moving to Russia and acquiring citizenship and, in particular, the abolition of the rule of obtaining citizenship on the basis of the TRP without additional conditions is more substantiated (Chudinovskikh 2014). Participants of the State Program and their families were the largest category of naturalized citizens for a number of years, up to 2019, when the main group of recipients of citizenship of the Russian Federation were inhabitants of southeastern regions of Ukraine who acquired the right to Russian citizenship on humanitarian grounds (Decree of the President... 2019b) (Table 3).

After the change of the division of territories into three categories in 2012 and the unification of them into two groups, priority settlement status was assigned to a number of territories of the following regions: the republics of Buryatia and Sakha (Yakutia), Zabaykalsky, Kamchatka, Primorsky, Khabarovsk Krai, Amur, Irkutsk, Magadan and Sakhalin Oblasts and the Jewish Autonomous Oblast. Exclusion of a number of regions from the priority (previously identified as strategically important) led to a reduction in the number of participants of the State Program (in 2013, the number of registered persons was 61\% of the 2012 level).

The extraordinary events in Ukraine and the decision of the Russian authorities to immediately allow persons granted temporary asylum to participate in the State Program contributed to the expansion of the number of applicants for participation. At the end of 2015, the number of persons registered as participants of the State Program and members of their families was three times as big as in 2013. Despite the obvious reasons for such dynamics, it was again attributed to the successes of the State Program itself.

The number of citizens of Ukraine who took part in the State Program increased sharply in 2014, their share among new participants increased by almost 6 times compared to the previous year (39.2\% in 2014 against 6.7\% in 2013). In 2015, the proportion of citizens of Ukraine among new participants reached a maximum of $60.2 \%$ of the total population resettled from abroad, and in 2016 it decreased to $42 \%$, simultaneously with a decrease in the inflow of forced migrants (data of the Ministry of Internal Affairs of the Russian Federation, on request). According to data of the following years, the share of the newly registered citizens of Ukraine in the total number of compatriots returned to the level of previous years: in 2017 it accounted for $26.6 \%$, in $2018-19.2 \%$, in $2019-11.7 \%$, including $5.8 \%$ for the IV quarter of 2019) (MIA of Russia 2017, 2018, 2019a).

Since 2015, the total number of registered participants fluctuated. In 2017 it amounted to 118.6 thousand people, in 2018 it decreased to 107.7 thousand people, in 2019 it amounted to 108.5 thousand people (MIA of Russia 2020b). At the same time, due to the relatively high increase in registered people in recent years, the number of registered has increased, which reached almost 900 thousand people in 2019.

In 2019, 65.1 thousand new applications for participation in the State Program were accepted from compatriots (153.3 thousand people), of which $51.5 \%$ of applications were submitted abroad (MIA of Russia 2019a). Among the applicants in the I quarter of 2020 most numerous were citizens of Tajikistan (32\%), Kazakhstan (23\%), Armenia (13\%) and Moldova (8.5\%). The citizens of Ukraine made up about $4 \%$ in the total number of applications (MIA of Russia 2020a).

According to the data announced by the head of the Main Directorate for Migration Issues (MDMI) of the Ministry of Internal Affairs of Russia V.L. Kazakova, in 2018 41\% of applicants had higher or incomplete higher education, 39\% had vocational secondary education. In addition, over $73 \%$ of participants of the State Program and members of their families belonged to economically active population, minors and pensioners made up 23.0 and 3.5\% respectively (Nezavisimaya Gazeta 2018). 


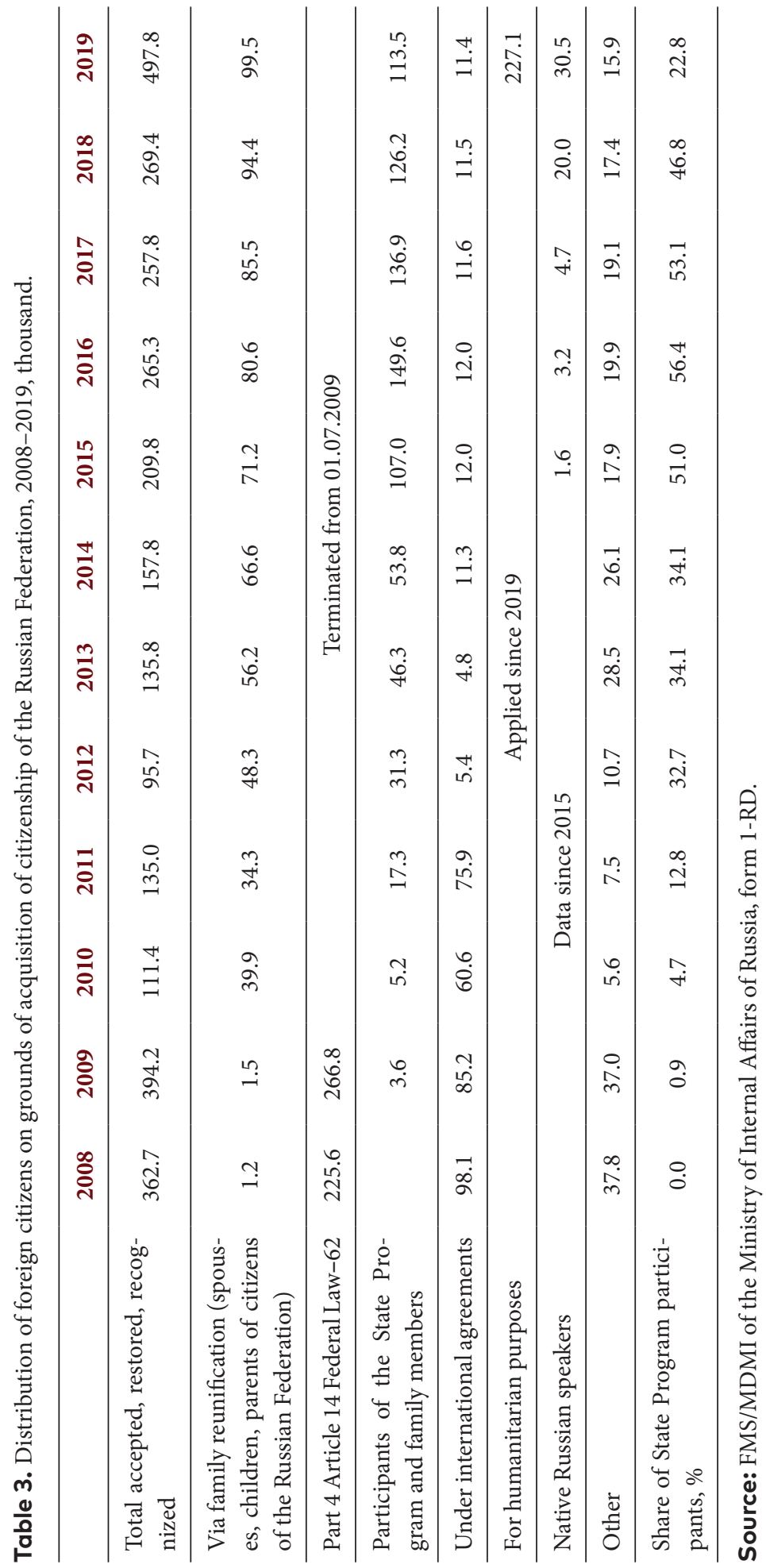


The decrease in the number of participants occurred against the background of increasing contradictions and inconsistencies during the implementation of the Program, including at the regional level, caused by a number of reasons: the desire of the regions to get a specific contingent of the working age population, inability to solve domestic problems of settlement of immigrants, limited local resources, which led to massive bureaucratic procrastination and denial of participation in the Program. So, in 2018 the Republic of Buryatia returned to the state budget 87 million rubles allocated but not spent on the arrangement of immigrants (Kommersant 2019).

Thus, the State Program, which is positioned as repatriation, has made almost impossible commitments, directly connecting humanitarian and economic functions. But despite many shortcomings and backdrops, it certainly has positive sides too. For the first time, a new organizational and legal mechanism for the Russian Federation to facilitate the return to Russia of a special category of people has been formed and is being improved. Work experience, including practical, can be useful in shaping a system of immigration programs for narrower, targeted categories of immigrants. To some extent the expectations of a country hosting a special category of migrants - compatriots - were met. In this case, we are referring to the expanded possibilities of adaptation and integration of Russian-speaking people adhering to Russian culture.

One possible way to further develop the Program is to gradually separate uncharacteristic functions from it and to improve the core of the Program using international experience. At the same time, the development of ethnic repatriation programs in other countries shows some general trends that are noticeably changing their original appearance.

\section{Ethnic repatriation programs: international context}

At present, the promotion of ethnic repatriation as a special type of immigration can be almost universally regarded as an additional attempt to address demographic problems, to compensate for the emigration flow and only in the least to restore historical justice. However, the extent to which the practice of returning former citizens and their descendants directly depends on the background of the issue, the conditions and scale of outflow of the population from the country, most often forced or voluntary, but under the influence of a number of negative circumstances.

The Second World War and its consequence - changing the borders of states, as well as the formation of new states as a result of the collapse of the USSR can be considered the main factors that had a marked impact on repatriation in the second half of the 20th and early $21 \mathrm{st}$ centuries. They have been an impetus for significant population movements and have thus far been an occasion for the establishment of repatriation programs to address current problems.

Repatriation programs in Germany and Israel are the most indicative examples of ethnic repatriation at the level of government programs. Among the post-Soviet states, the program of ethnic repatriation has gained noticeable proportions perhaps only in Kazakhstan. The less successful experiences of some other countries will also be mentioned further.

\section{Germany}

In the post-war years, the return of resettlers and refugees can take place both spontaneously and with the participation of the state and international organizations. It is generally an ethnically mixed stream. Over time, repatriation, including ethnic, becomes the task of the host 
state. In this historical context, a program of repatriation of ethnic Germans to Germany was formed.

In fact, the current repatriation program no longer plays a large role in the replenishment of Germany's population, although it has been an important focus of immigration policy for a long time. Over 4.5 million Germans and their families returned to the country during the entire period of the implementation of the programs for the reception of immigrants (from the beginning of the 1950s to 2018). Historically, two waves of immigration of ethnic Germans with families are significant - in the 1950s and 1990s (the first is caused by changes in the postwar political map, the second is the result of changes in legislation and, mainly, the collapse of the USSR). During the period of late repatriation in Germany, the procedure for proof of German nationality was facilitated and allowed for wider interpretation. As a result, modern descendants of ethnic Germans arriving in the country do not always have the necessary potential for successful integration (Hess and Green 2016).

The adoption of the first laws regulating the repatriation process was driven by the need to address the problems of the return of ethnic Germans after the Second World War. Originally (until 1948), laws were passed at the level of the individual lands of West Germany. The status of a repatriate, which in many cases was difficult to document, was established mainly as belonging to the German ethnic group (Baraulina 2003). The basic law of Germany (Constitution, adopted on May 23, 1949, Article 115) enshrined the general characteristics of persons of German nationality and uniform rules for determining the status of a repatriate. This law played a special role, almost putting the rights of German repatriates on a par with the rights of citizens for many years. Because of this law, settlers were not actually considered migrants per se, which made it more difficult to regulate the settlement process, especially in the early 1950s.

Since 1953, after the adoption of the The Federal Law on Refugees and Exiles (German: Bundesvertriebenengesetz, BVFG) clear grounds for obtaining the status of resettled (this law, periodically supplemented and updated, is still valid) have been determined. In the early stages, the criterion for inclusion in the category of returnees was the situation of forced change of residence (political repression, threats, expulsion, ethnic persecution) followed by the return to German territory. Since 1957, individuals, as well as their children and grandchildren with families who were outside Germany, but who had lived before 1945 in the territories of war and were subjected to persecution, obtained the possibility to become returnees. The law adopted in 1953 was the starting point for the formation of measures of support for returnees, it "defined measures for special social support and assistance to German victims during the war, the financial responsibility of various administrative levels of government was distributed" (Baraulina 2003).

After a relative calming in the 1960s-1970s (in the absence of free movement from the socialist bloc), new ways for repatriation opened. In 1988, after the permission of leaving the USSR “on private matters" (reunification with family members, marriage, meeting with relatives, etc.), adopted in 1987, against the background of the increase of the flow the program of integration of immigrants (the so-called "H. Kohl's program") was initiated, involving mutual rapprochement and cultural enrichment of indigenous people and resettlers. But already by 1989 it was necessary to tighten the admission procedure. According to the Law on on securing the place of residence for late migrants (entered into force on July 15, 1989), returnees must be registered in federal resettlement camps and then distributed to regions according to the direction of the camp. Since 1997, resettlers were to remain in the initial settlement sites until they find permanent employment and provide for themselves. The 
quotas in force at this time (225 thousand people per year from 1993 to 1999, 103 thousand people in 2000) weakened the flow (Bolshova 2012).

Beginning in 1993, ethnic Germans who moved to Germany became officially known as "late resettlers" (German: spätaussiedler, although this concept appeared earlier). This period marked changes in the reception of returnees, which preserved many of its features to this day. The status of a resettler was given to persons born before 1993 who lived in the former republics of the USSR (except the Baltic ones), who had German origin; knew German language; were committed to the German people and had no other impediments to obtaining the status. Those born after 1993 cannot move to Germany under the repatriation program.

Modern terms of resettlement, formulated in the amendments to The Federal Law on Refugees and Exiles (adopted on September 6, 2013), take into account three categories of kinship - late migrant; a spouse who has been married for over 3 years and descendants of a resettler; a spouse who has been married for less than 3 years and other family members. The first two categories of immigrants are granted citizenship and an opportunity to take integration courses for free. Recognition as a late migrant practically means immediate acquisition of citizenship, and retention of previous citizenship may also be possible. Representatives of the first group can also receive an integration allowance, a pension for work experience beyond Germany and other benefits. There is also an option to receive a pension from abroad instead of the latter, which is actively used by former citizens of Russia (Pension... 2019). Individuals from the third group receive only a TRP or a residence permit.

There is currently one camp for German immigrants in Germany (Friedland) where they go through primary registration (since 2007, many of them attend integration courses here) and are further distributed to federal lands in Germany, where the final procedure for recognition as late resettlers is under way. Upon arrival in the country, immigrants receive compensation of the cost of entry (the amount depends on the country of origin), and upon arrival in the center - of funds for initial expenses. As German citizens, returnees can receive social benefits for citizens - unemployment, children, etc.

Thus, the policy of supporting ethnic (German) repatriation in Germany is quite consistent. This is one of the most prominent examples in which repatriation itself (as return after the settlement of conflict) takes a new form of conditional repatriation, the main participants of which are descendants of former refugees and emigrants. At the same time, the ethnic component itself is gradually becoming blurred when, in the face of the growing need for additional populaiton, the circle of participants is expanding to a greater extent indirectly rather than directly, and includes persons confirming their affiliation with the German people. And despite the fact that this process has not led to a dramatic change in the composition of ethnic returnees in Germany (these are descendants of Germans), it is increasingly difficult for late immigrants to preceive their identity. Identity issues still matter. According to the researcher, on the example of ethnic repatriation to Germany from Russia, it is possible to trace how, own ideas about German identity - "own narrative of identity and family history" - are formed in the process of passing "filters" during repatriation (Zeveleva 2014). Problems of integration, according to A. Fatianova are some twofold measures: assistance provided at the initial stage of stay in the country is available in the confined space of the camp and does not in fact stimulate external communication (Fatyanova 2011). That is why the integration block of the program can be considered sufficiently developed in the country, which 
ensures universal accessibility to a number of integration courses, including language courses, on a free basis.

Comparing the policy of repatriation in Germany and Russia, experts note a certain similarity of tasks and problems (formation of a new national identity within the changed state borders and composition of the population) and at the same time their different effects (Zeveleva 2013). Based on available statistics, it can be noted that in the last decade the number of resettlers has significantly decreased (Fig. 1).

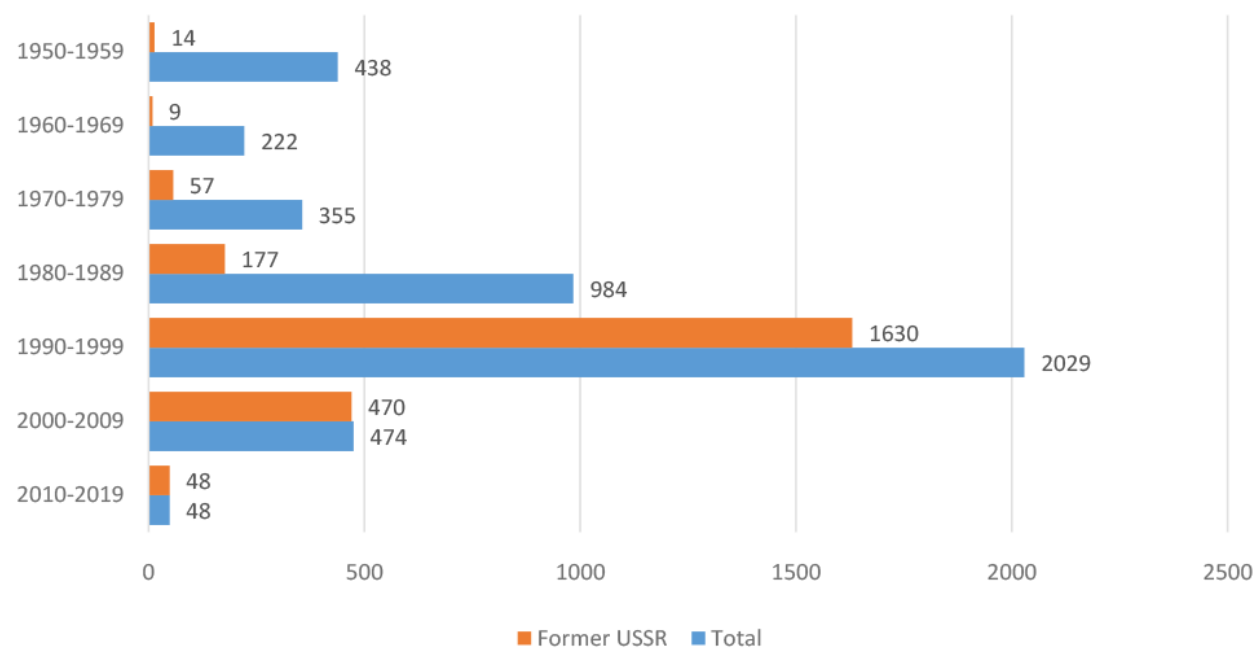

Figure 1. Number of resettlers to Germany and their family members, 1950-2018, thousand people. Source: (BVA 2020).

The last peak of resettlement, both in Russia and Germany, came in the first decade after the collapse of the USSR. In the near future, it is difficult to expect a significant increase in the intensity of repatriation to Germany even of late resettlers, although apparently persons born before 1992 and with German origin, has not yet completely been exhausted.

Common to the resettlement programs in Russia and Germany was the fact that, despite the openly recognized humanitarian mission, the flow of ethnic returnees was restrained at certain stages. At the same time, in both cases the interest of the territories of settlement was taken into account: in Germany - by setting quotas for entry, in Russia - due to the need to comply with the demands of the local labour market. Nevertheless, in Germany, returnees were not openly required to have vocational qualifications in demand on the labour market, that was more in line with humanitarian goals. Once a positive decision has been made, returnees in Germany can live in a resettlement camp for a certain time before employment and housing problems are resolved. Repatriates in Russia must present in advance the nature of their employment in the territory of entry and comply with the requirements of the labour market. The main difference between two programs is due to the fact that the main decisions were made in different historical contexts - in Germany in the 1990s at the time of the collapse of the USSR, in Russia after the main flow of returnees had decreased substantially. 


\section{Box 2}

The repatriation program of late resettlers in Germany has, in some ways, become an example for similar programs in several other countries in Europe, for example, in Poland. A similar historical context - the deportation of the Polish population in the 1930s and 1940s both by the Soviet government and by Germany - caused some commonality of approaches to the implementation of the programs.

As in Germany, two main laws governing repatriation in Poland are the Constitution (grants the right to live in Poland to all persons of Polish descent) and the Repatriation Act of November 9, 2000 (augmented in 2017). An immigrant who receives a repatriation visa (including a minor in the care of parents) acquires Polish citizenship at the time of crossing the Polish border. As well as in Germany, you can live in an adaptation center in Poland (in aggregate up to half a year), learn the language, take adaptation courses, while at the same time looking for work. Now there are two such centers. Assistance is provided in the form of settling allowance, reimbursement of funds spent on moving, assistance may be provided for renovation of the accommodation, etc. After 2017, obtaining citizenship for spouses with no Polish roots became easier. The modern Polish program also clearly restricts the territory of exit - only a person of Polish origin who had lived before 2001 in the Asian territories of the former USSR can become a returnee. The total number of returnees in 1997-2018 in Poland amounted to 10 thousand people (Demographic... 2019).

\section{Israel}

Unlike many countries of classical repatriation, Israel can be described as a unique state based on the process of ethnic repatriation "to the historical homeland" (aliyah). The Declaration of the establishment of the state of Israel proclaimed that "the state of Israel will be open for Jewish immigration and for the ingathering of the exiles; to the Jewish people throughout the diaspora to unite around the Jews of Eretz-Israel in solving the problems of immigration and construction" (Declaration... 1948).

The basic law governing repatriation, currently the Law on return (adopted on July 5, 1950), defines the right of Jews to repatriation and the possibility of obtaining citizenship. A Jew who arrives in the country under the Law on return shall receive the status of a citizen automatically (under the Citizenship Act of 1952). In addition to ethnicity, it was necessary to fulfill the requirement of confessional affiliation (Judaism). Since then, a national program has been formed, which now involves multiple settlement options, including different subprograms, taking into account the needs of different categories of the population.

For a long time, in Israel, against the background of significant migration from post-Soviet countries and Russia, important directions of change of legislative initiatives have been discussed - clarifying the affiliation of the Jewish ethnicity and confessional criteria. Thus, in accordance with the amendments to the Law on return and the Law on population registration (March 1970), "in application to this Law, one who is born to a Jewish mother and did not convert to another religion as well as a person who accepted Judaism is considered a Jew". At the same time, the Law on return is extended to children and grandchildren of Jews and their families (regardless of religion) who receive the same status as returnees. In 2014, for the first time non-Jews under the Jewish religious law of Halakha were given the opportunity to live in a Jewish state with a temporary visa immediately after conversion to Judaism in the case it has been done abroad. Previously, in such a case, they had to stay in the country of origin for 9 months. 
In some cases the established and long-standing retreats have led to a gradual erosion of the confessional unity of returnees. According to the Ministry of Internal Affairs of Israel (December 2019), the number of non-Jews - new Israelis who came to the country since 2012 from the republics of the former USSR is large: among returnees from Russia it is $61.5 \%$, from Ukraine $-66 \%$ (most of the new Israelis who came from the United States and France at the same time are Jews according to halachic canons, only $5 \%$ of returnees from the United States and 4\% from France are not Jews) (Nakhshoni, 2019).

Other conditions for obtaining citizenship gradually changed. After 1971, any Jew outside Israel was be able to obtain Israeli citizenship at will. And since 1999, people who have married an Israeli citizen are not automatically granted citizenship.

Perhaps no country in the world has such an extensive system of assistance and measures targeted at returnees as Israel. The system of measures takes into account many nuances and characteristics of returnees: family, age, profession, etc.

The Ministry of Aliyah and Integration is responsible for providing basic assistance. An "absorption basket" - financial assistance for settling at the initial stage, is available to all returnees. It includes a certain amount - the means of subsistence for the period of study in ulpan (six months) and grants for rental of housing for the first year of life in Israel. The first payment for the "basket" is made directly upon arrival. Further payments are made once a month during half a year. The amount of funds for rent depends on the composition of the family (married couple, incomplete family, single person) and the age of returnees (separately for families of pre-retirement, retirement age, children). After 6 months, disabled persons may receive a living wage allowance. During the year, returnees do not pay income tax.

Different absorption options are offered for different categories of population. Direct absorption involves relative autonomy of actions (housing rental, signing up for an ulpan to study Hebrew). Separately, there is the possibility of a short stay in the Absorption Center after arrival, which allows time to find an apartment for rent. The Ulpan-Kibbutz Youth program provides an opportunity to combine language learning with work. The Aliya-2000 program aims to study the language and prepare for university examinations and retraining courses. There are also paid programs, such as "First house in the motherland". Members of the program - families - can rent a house in a kibbutz where they can learn the language, eat, use kindergarten and school services.

Undoubted interest has been attracted by the "Negev and Galilee" program, which operated in 2016-2018 (a special project for the development of two cities within the framework of the state program of the Ministry of Periphery Development of Israel). In 2017, 6.9 thousand returnees participated in the program, in 2018 - 3.2 thousand.

Israel has developed and is expanding an entire range of integration activities and programs, including employment programs, assistance to those wishing to start a business in Israel, special program vouchers to study Hebrew, etc.

There are also various programs for potential returnees to Israel, including those developed by well-known organizations, MASA and NAALE, with the participation of the state. Programs are offered for different categories of people: students; professionals who want to improve qualifications; singles planning to start a family abroad; pensioners. Many programs, especially the training ones, do not formally declare the aim of acquiring Israeli citizenship, but their very structure aims to real repatriation immediately upon program completion.

The state's multilateral assistance to returnees is yielding results. According to the Ministry of Internal Affairs of Israel, 199.9 thousand people have received Israeli citizenship in 
accordance with the Law on return since 2012. At the same time, 37.5\% of new citizens were not recognized as Jews (Maltz 2019). Since 1990, the main part of the stock are returnees from post-Soviet countries, primarily Russia (Fig. 2). From 1970 to 1988 about 164 thousand Soviet Jews and their families moved to Israel, and from 1989 to 2018 emigration from post-Soviet countries already amounted to 1.1 million people (Tolts 2019).

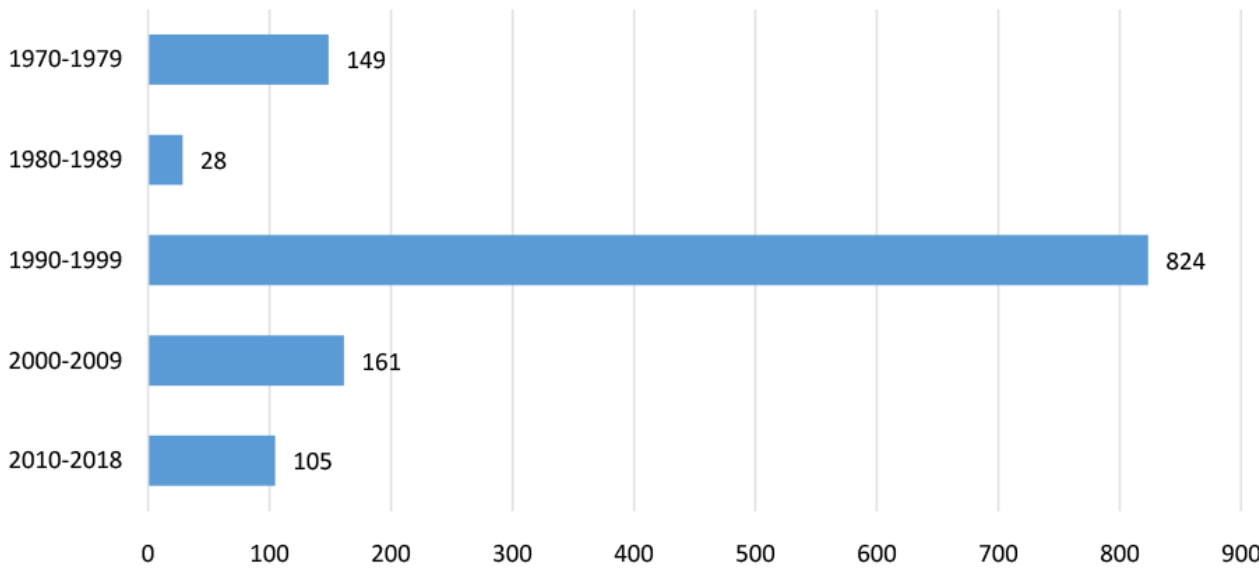

Figure 2. Number of Jews and their families who moved to Israel from the USSR and the countries of the former USSR, 1970-2018, thousand people. Source: Compiled according to data (Tolts 2019).

The program of ethnic repatriation to Israel has no analogues in the world. It has been and continues to be an effective tool for attracting new citizens of Jewish descent into the country. A characteristic feature is the diversity of subprograms with different target audiences, which makes the program more selective and flexible.

The advantage of the extensive system of programs is a differentiated approach to participants, demonstrates the desire a desire to attract population needed to replenish the labour force to the country; to achieve it a whole cluster od subprograms is created, including training and retraining. This approach is almost undeveloped in the Russian State Program.

The Israeli program, despite its long period of operation, retains its position as the dominant source of population replenishment. At the same time, the concurrent requirement of confessional affiliation and the amendment relating to the relatives of returnee Jews are a source of intense debate.

\section{Countries of the post-Soviet space}

Ethnic repatriation programs are not an obligatory part of the state's migration policy, although in many countries, including the post-Soviet space, historical precedents for their developments exist. However, not all countries that even declare support for the return to their homeland of ethnically related populations or peoples traditionally residing in the territory of the state are coping with their obligations.

After the collapse of the USSR, such programs began to appear in former Soviet republics. For example, ethnic repatriation of Latvians and Livonians to Latvia is welcome at the state 
level (the Law on repatriation was adopted in 1995), but the annual number of arrivals after 2000 did not exceed 300 people.

In 2019, it was reported that the Lithuanian Seimas adopted a law allowing to relocate persons of Lithuanian origin "from crisis zones" to the republic. It is expected that the source of replenishment will be the community of Lithuanians living in Venezuela (Sputnik 2019): the country, in the context of the active outflow of population that began after Lithuania's accession to the EU, no longer relies on less geographically remote replenishment sources.

Georgia, which in 2007 adopted the Law "On the repatriation of persons forcibly resettled from the Georgian SSR in the 1940s by the authorities of the former USSR" and undertook the repatriation of Meskhetian Turks to Georgia, ultimately refused to accept them.

For a number of years Armenia has positioned itself as a country that supports ethnic repatriation. The Constitution of 1995 grants the right to citizenship to persons of Armenian ethnicity living abroad. It was reported about the Concept of organizing the repatriation process (Building... 2011) and other documents adopted in 2010, but in practice it all comes down to attempts to attract the foreign diaspora to economic participation in the life of the country, and most of the advertised repatriation initiatives are private.

Analyzing the experience of supporting ethnic repatriation in the post-Soviet states, it can be concluded that only in Kazakhstan the program of ethnic repatriation became more or less effective and scaled.

\section{Kazakhstan}

Despite the fact that implementation of the repatriation program in Kazakhstan was overshadowed by a number of serious problems throughout the years of state-supported programs the number of ethnic returnees exceed 1 million people.

The policy of returning ethnic Kazakhs living abroad - the Oralmans - began to form as a government program already in the 1990s, almost immediately after gaining independence.

Since the beginning of the 1990s, the country has undergone several stages of policy formation for returnees, and there was not a single cross-country repatriation program in the country.

In the 1990s, program provisions supported the idea of restoring historical justice, for which it was decided to stimulate immigration of ethnic Kazakhs affected by repressions and forced collectivization, who emigrated mainly in the 1930s. In November 1991, the decision of the Government of the Republic of Kazakhstan "On the procedure and terms of resettlement to the Kazakh SSR of persons of indigenous ethnicity who have expressed desire to work in rural areas, from other republics and foreign countries" (the document was released against the background of the current outflow of rural residents to cities). The rules for ethnic repatriation (establishment of repatriation quotas and financial allowance for adaptation and resettlement in the regions) were established in 1992 by the Law on immigration. The quota system has been used since 1993 (although it was officially approved in 1997), while there were no territorial restrictions on resettlement.

The start of the program was optimistic. In 1991-1992 over 60 thousand ethnic Kazakhs returned to the republic (Sultanmuratov 2017). But by the mid-1990s, returnees had become more and more open about difficult socio-economic conditions, their privileged status had gradually lapsed, while socio-economic problems made them vulnerable. The annually adopted quotas have decreased since 1993 (from 10 thousand families originally to 500 in 1999-2000). 
In the 2000s, the assessment of returnees as a source of labour (amid the growing need for cheap labour) came to the forefront. The distinctions of returnee Oralmans from indigenous populations have become more noticeable. At the end of the period, the program of repatriation "Nurly-Kosh" (approved by the Decree of the Government of the Republic of Kazakhstan of 2.12.2008 № 1126, the period of implementation: 2009-2011). It was essentially a program of "regional and rural development and industrialization of the country", which, along with ethnic returnees, provided for the participation of migrant workers from abroad and internal migrants. It was assumed that migrants would move to remote areas in the north, east and west of the country.

In 2009-2011, it was planned to spend 2 billion tenge (about 1.3 billion dollars) on the development of small urban centers with a certain specialization and common labour market. As a part of 45 innovative projects, 39 thousand workers were needed (they were guaranteed state support, including housing benefit). Compact settlements for returnees were built to provide housing (with loans from the central budget to local authorities). It was planned to provide housing for 3269 families. There were few people wishing to go to the poor areas of Kazakhstan. From 2009 to 2011, the quota for ethnic returnees eligible for social benefits was 20 thousand families per year ( 2 times as big as in 2005-2007), but it was fulfilled only by $36 \%$. The isolation of settlements limited communication with the local population and made adaptation and integration difficult. By the end of 2011 there was a conflict in one of the settlements of oil workers (the city of Zhanaozen) for ethnically ethnic "other" migrants were blamed.

A review of the counting board revealed the "fragmented nature of the program implementation" and it was stopped. The government ceased to monitor its implementation, transferring responsibility to local authorities.

After 2014, the policy of stimulating voluntary resettlement resumed (against the background of the Ukrainian crisis and Russia's unification with Crimea) in order to change the demographic balance in North Kazakhstan. However, later attempts to direct repatriation to the northern regions (decrees of 2014), in the context of restricting social benefits to returnees, actually led to a change in the participants: most returnees had no professional education and could not actually replace the outgoing Russian and other population. The reduction of the time for citizenship acquisition to a year, that meant loss of some of the social benefits, was a complication.

In 2016, state experts put forward a proposal to give priority to young ethnic returnees who theoretically would be easier to adapt and obtain higher education in Kazakhstan (Dukeuev 2018). Such a repatriation has its benefits because only young people come, not whole families that include older generations.

Overall, the implementation of repatriation programs has proved more difficult than expected. Isolation in individual settlements, absence of knowledge of the Russian language necessary for daily communication by returnees who arrived from outside the former USSR (mainly from China and Mongolia) caused tensions with the population and local administrations.

Currently, there is a decrease in the amount of supported repatriation of Oralmans who arrive in Kazakhstan both by quota (to selected regions) and on the quota-free basis (these returnees may be established in other regions as well). If in 2019 the regional quota of reception of Oralmans in the amount of 2031 people (distributed among 5 districts of Kazakhstan) was approved (Forbes 2019), in 2020 the quota is already 1,378 people (Inbusiness.kz 2020). At the same time in 2019, 17,661 people arrived and received the status of Oralman. In 2019, they received support within the framework of the implementation of the State 
program for the development of productive employment and mass entrepreneurship for 2017-2021 "Yenbek", including: for relocation - payment to each family member of $35 \mathrm{MCI}$ (84.2 thousand tenge; MCI is a monthly calculation index, used in Kazakhstan to determine social payments); to cover the cost of housing let and payment of utilities - monthly during the year from 15 to $30 \mathrm{MCI}$ (from 36.1 to 72.2 thousand tenge per family).

Thus, the number of Oralmans arriving outside of quotas and receiving no additional benefits now exceeds the number of those arriving by quota. At the same time, they can settle in other areas, usually southern, exacerbating the imbalance of population settlement across the country.

According to data for 2019, the share of Oralmans who arrived from China accounted to $41.5 \%$, from Uzbekistan $-40.1 \%$, Turkmenistan $-6.5 \%$, Mongolia $-6.2 \%$, from Russia only $1.8 \%$ (Forbes 2019). Most Oralmans adhere to slightly different cultural traditions and values typical of eastern communities and try to settle compactly. The level of education and professional qualifications of returnees are generally relatively low. And the availability of social benefits for Oralmans causes discontent of the local population, which often also needs help. This gives rise to negative attitudes towards Oralmans in general.

In the Concept of migration policy of Kazakhstan, the process of ethnic migration is characterized by: "uneven settlement of ethnic returnees in regions of the country without regard to their needs in the labour force; low socio-cultural integration of ethnic returnees into the Kazakh society, taking into account differences of outlook and linguistic barriers; low qualification of ethnic returnees and ineffective measures of their employment and adaptation; insufficient awareness-raising work among representatives of the Kazakh diaspora abroad" (Resolution... 2017). The practice of implementing programs in Kazakhstan warns against errors related to lack of attention to the problems of adaptation and integration of returnees.

However, it is impossible to deny that the main goals of migration policy have been achieved, the population has grown, the ethnic composition of the population has changed the share of the title population has increased (from 40.1\% in 1989 (census) (Alekseenko 2001 ) to $68 \%$ (estimate at the beginning of 2019, calculated according to (Demographic... 2019)). Modern conditions for receiving ethnic returnees of Oralmans, regardless of education, qualification, country of origin, can be referred to as relevant humanitarian principles of repatriation programs.

\section{Concluding remarks}

Thus, when considering ethnic repatriation programs that have been successful, it can be noted that their results depend on influence of completely different factors.

The Russian State Program bears some resemblance to repatriation programs implemented in other countries. This refers to the set of measures to promote repatriation and financial support provided to resettlers. At the same time, in quantitative terms, the funds allocated in Russia do not bear comparison with the assistance provided in countries like Israel or Germany.

Common is an attempt to achieve territorial distribution of returnees, not throughout the territory, but to selected regions of the country. As in Kazakhstan, for example, Russia has identified priority resettlement territories with a strengthened set of benefits (in Kazakhstan, Oralmans who arrived to other areas or outside quotas are not granted privileges). 
Professional skills requirements (level of education demanded in the region of profession) at the stage of the decision on reception of returnees are openly presented only by regional subprograms in Russia.

The low performance of the State Program is primarily due to the fact that it is a consequence of the wrongly chosen strategy, the purpose of which was not to facilitate the repatriation of ethnoculturally close people, but a pragmatic solution to a whole range of regional problems, among which the problem of shortage of labor resources of a certain quality took the dominant position. The new Concept of the state migration policy of the Russian Federation for 2019-2025 actually establishes the current state of affairs. The document refers to the need to attract skilled workers and other categories of foreigners capable of contributing to the development of the country (Decree of the President... 2018b). But in the end, all the provisions of the Concept related to the migration of skilled personnel again fit into the context of the State Program.

In order to improve the effectiveness of the Program, its repatriation character should be clearly defined by removing the unreasonable requirements that are appropriate in labour migration programs. Of course, it is necessary to remove the strict economic requirements for potential participants. Diversified channels of migration, both temporary and permanent residency, can be offered for returnees from different sociodemographic groups. This will make the Program more flexible and coherent in sense, increase its appeal to a wider range of potential migrants. Israel's successful experience - the availability of assistance programs for students, young people wishing to continue their studies, selected opportunities for families and other categories of ethnic migrants - shows possible ways of improvement of the Russian Program. Thus, moving to Russia with a family should not be a criterion of eligibility (which is found at the regional level), but one of the ways of repatriation that takes into account the family composition. Special attention should be paid to the children of returnees and their further education, including in the areas demanded by the economy of the region, as well as to young people. The experience of Israel is also noteworthy in this sense, in which there are separate programs - study trips and internships for young people in a country of potential immigration. In turn, the attraction of specialists with the professions and competencies required by the country should be allocated to a separate channel of labour migration, without associating the movement of these people with ethnocultural proximity to Russia, their origin, etc.

Since the initial adaptation period is closely linked to the solution of settlement problems, attention should apparently be drawn to the experience of both Israel and Germany overseeing their returnees in providing housing. Providing temporary housing and housing subsidies within a certain period will partially remove the problem of settlement, and in less demanded priority settlement regions direct payments for the provision of ready housing may be provided.

Different types of assistance that contribute to the adaptation and further integration of resettlers cannot be neglected since our modern compatriots comprise a very diversified group, distinguished by ethnic diversity.

Analysis of a number of repatriation programs showed that their success depends on the consistent implementation of the main objectives of a program. In doing so, the state must have necessary resources to achieve these goals. Otherwise, the program loses its attractiveness or, as it happened in Kazakhstan, causes increase in tensions and conflicts.

The lack of resources at places dooms new compatriots to additional tests, and the desire to replenish the country's labour force through this channel and to establish for these pur- 
poses rigid criteria effectively deprives the Program of a humanitarian component, making it predominantly an economic migration program, "imitating" a repatriation one.

The article was prepared with the financial support of the Russian Foundation for Basic Research (RFBR) within the framework of the scientific project №19-010-00670\20 "Evaluation of the results of the implementation of the migration policy of the Russian Federation and proposals for its modernization in new economic and geopolitical conditions".

\section{Reference list}

Alekseenko A (2001) The first census of the population in sovereign Kazakhstan: some results and estimates. In: Vitkovskaya G, Zayonchkovskaya Zh (Eds) Migration in CIS and Baltic states: to a common information space through the difference in problems, St. Petersburg (Russia), September 2000. Adamant, Moscow, 82-98. (in Russian)

Arefyev A (2006) How many people speak and will speak Russian? Demoscope Weekly (251-252). http://www.demoscope.ru/weekly/2006/0251/tema05.php. [Accessed on 17.07.2020] (in Russian) Baraulina T (2003) State construction of reality: social consequences of migration policy, Rubezh (al'manakh sotsial'nykh issledovanii) [Threshold (almanac of social studies)] (18): 65-110. http:// ecsocman.hse.ru/data/475/862/1217/18_04.pdf. [Accessed on 17.07.2020] (in Russian)

Bolshova NN (2012) Germany' immigration policy towards highly-skilled workers in $21^{\text {st }}$ century. Vestnik MGIMO [Bulletin of MGIMO] (6): 226-237. https://mgimo.ru/library/publications/1003582/?sphrase_id=28662701 [Accessed on 17.07.2020] (in Russian)

BVA (2020). Spätaussiedler und ihre Angehörigen. Zeitreihe 1950 - 2019. URL: https://www.bva.bund. de/SharedDocs/Downloads/DE/Buerger/Migration-Integration/Spaetaussiedler/Statistik/Zeitreihe_1950_2019.pdf;jsessionid=8153C4260AD81D4EE3BE564A1785DA01.intranet261?_blob=publicationFile\&v $=5$

Chesnokov A (2008) The return of compatriots as a tool of immigration policy. Mezhdunarodnye protsessy [International processes]. 6 (17): 79-85. http://intertrends.ru/rubrics/fiksiruem-tendentsiyu/journals/krizis-i-perspektiva/articles/vozvraschenie-sootechestvennikov-v-immigratsionnoy-politike. [Accessed on 17.07.2020] (in Russian)

Chudinovskikh OS (2014) On the policy and trends of acquisition of citizenship of the Russian Federation in the period from 1992 to 2013. Demograficheskoe obozrenie [Demographic Review] 1 (3): 65-126. https://demreview.hse.ru/article/view/1810. [Accessed on 17.07.2020] (in Russian)

Chudinovskikh OS (2018) Statistics on citizenship acquisition as a reflection of the peculiarities of the russian migration policy. Voprosy statistiki [Issues of statistics] 25 (9): 3-26. https://elibrary.ru/ item.asp?id=35781092 [Accessed on 17.07.2020] (in Russian)

Declaration of Establishment of State of Israel (1948) May 14. https://mfa.gov.il/mfa/foreignpolicy/ peace/guide/pages/declaration\%20of\%20establishment\%20of\%20state $\% 20$ of $\% 20$ israel.aspx. [Accessed on 17.07.2020]

Decree of the Head of the Republic of Sakha (Yakutia) (2017) "On the State Program of the Republic of Sakha (Yakutia) 'Development of the labour market and promotion of employment of the population of the Republic of Sakha (Yakutia) for 2018-2022”’ of 04.12.2017 № 2258. http://docs.cntd. $\mathrm{ru} /$ document/543709013. [Accessed on 17.07.2020] (in Russian)

Decree of the Head of the Republic of Sakha (Yakutia) (2019) "On amendments to the State program of the Republic of Sakha (Yakutia) 'Promotion of employment of the population of the Republic of Sakha (Yakutia) for 2020-2024', approved by the Decree of the Head of the Republic of Sakha 
(Yakutia)” of 10.12.2019. № 874. http://portal.b14.ru/wp-content/uploads/2020/02/Ukaz-GlavyRSYA-ot-10.12.2019-874.docx. [Accessed on 17.07.2020] (in Russian)

Decree of the President of the Russian Federation (2012) "On the implementation of the State Program of assistance to voluntary resettlement to the Russian Federation of compatriots living abroad" of 14.09.2012 № 1289. http://publication.pravo.gov.ru/Document/View/0001201209170003. [Accessed on 17.07.2020] (in Russian)

Decree of the President of the Russian Federation (2013) "On amending the Decree of the President of the Russian Federation of 14.09.2012 № 1289 'On the implementation of the State Program for assistance to voluntary resettlement to the Russian Federation of compatriots living abroad" of 14.06.2013 № 565 http://publication.pravo.gov.ru/Document/View/0001201306140021. [Accessed on 17.07.2020] (in Russian)

Decree of the President of the Russian Federation (2014) "On amendments to the State Program of assistance to voluntary resettlement to the Russian Federation of compatriots living abroad, approved by the Decree of the President of the Russian Federation of 22.06.2006 № 637” of 25.07.2014 № 531. http://publication.pravo.gov.ru/Document/View/0001201407250008. [Accessed on 17.07.2020] (in Russian)

Decree of the President of the Russian Federation (2018a) "On amendments to certain acts of the President of the Russian Federation on issues of implementation of the State Program of assistance to voluntary resettlement to the Russian Federation of compatriots living abroad” of 15.03.2018 № 109 http://publication.pravo.gov.ru/Document/View/0001201803150006. [Accessed on 17.07.2020] (in Russian)

Decree of the President of the Russian Federation (2018b) "On the concept of state migration policy of the Russian Federation for 2019-2025” of 31.10.2018 № 622. http://publication.pravo.gov.ru/ Document/View/0001201810310046. [Accessed on 17.07.2020] (in Russian)

Decree of the President of the Russian Federation (2019a) "On amendments to the State Program of assistance to voluntary resettlement to the Russian Federation of compatriots living abroad, approved by the Decree of the President of the Russian Federation of 22.06.2006 № 637” of 31.05.2019 № 248. http://publication.pravo.gov.ru/Document/View/0001201905310008_[Accessed on 17.07.2020] (in Russian)

Decree of the President of the Russian Federation (2019b) "On amendments to the Decree of the President of the Russian Federation of 29.04.2019 № 187 'On certain categories of foreign citizens and stateless persons entitled to apply for admission to citizenship of the Russian Federation in a simplified manner” of 17.07.2019 № 343 http://publication.pravo.gov.ru/Document/ View/0001201907170036 [Accessed on 17.07.2020] (in Russian)

Decree of the President of the Russian Federation (2019c) "On the implementation of the State Program of assistance to voluntary resettlement to the Russian Federation of compatriots living abroad" of 24.07.2019 № 354. http://publication.pravo.gov.ru/Document/View/0001201907240025. [Accessed on 17.07.2020] (in Russian)

Decree of the President of the Russian Federation (2020a) "On amendments to the State Program of assistance to voluntary resettlement to the Russian Federation of compatriots living abroad, approved by the Decree of the President of the Russian Federation of 22.06.2006 № 637” of 11.03.2020 № 179. http://publication.pravo.gov.ru/Document/View/0001202003110063. [Accessed on 17.07.2020] (in Russian)

Decree of the President of the Russian Federation (2020b) "On some issues of implementation of the State Program of assistance to voluntary resettlement to the Russian Federation of compatriots living abroad” on 12.05.2020 № 322. http://publication.pravo.gov.ru/Document/View/0001202005130006 [Accessed on 17.07.2020] (in Russian) 
Demographic statistics. 21 series. Population of the Republic of Kazakhstan by individual ethnic groups as of the beginning of 2019. (http://stat.gov.kz/api/getFile/?docId=ESTAT306055) [Accessed on 17.07.2020] (in Russian)

Demographic Yearbook of Poland (2019) Statistics Poland Warsaw 2019. https://stat.gov.pl/download/gfx/portalinformacyjny/en/defaultaktualnosci/3328/3/13/1/demographic_yearbook_of_poland_2019.pdf. [Accessed on 17.07.2020]

Denisenko M, Chudinovskikh O (2017) Reasons for failure to implement the provisions of the Concept of state migration policy of the Russian Federation. Demoscope Weekly. (753-754) http:// www.demoscope.ru/weekly/2017/0753/analit01.php [Accessed on 17.07.2020] (in Russian)

Dukeuev B (2018) Ethnic return migration in Kazakhstan: Shifting state dynamics, changing media discourses. CAP Papers 183. https://centralasiaprogram.org/archives/10616 [Accessed on 17.07.2020]

Fatyanova AV (2011) Features of adaptation of immigrants on the example of late immigrants in Germany. In: Minaev VV (2011) Global demographic problems of modern times: Migration and migration policy. RGGU, Moscow, 259-269. (in Russian)

Federal Law (1999) “On the state policy of the Russian Federation for compatriots abroad” of 24.05.1999 № 99-FL. Part 3, Article 1. http://www.kremlin.ru/acts/bank/13875. [Accessed on 17.07.2020] (in Russian)

Federal Law (2018a) "On amendments to the Federal Law 'On features of providing land sections in state or municipal ownership and located in the territories of the constituent entities of the Russian Federation, which are part of the Far Eastern Federal Okrug to citizens, and on amendments to certain legislative acts of the Russian Federation' and Article 3 of the Federal Law 'On the turnover of agricultural lands”' of 27.12.2018 № 503-FL. https://rg.ru/2018/12/29/zemli-dok.html. [Accessed on 17.07.2020] (in Russian)

Federal Law (2018b) "On customs regulation in the Russian Federation and on amendments to certain legislative acts of the Russian Federation” of 03.08.2018 № 289-FL. http://www.kremlin.ru/acts/ bank/43499/print. [Accessed on 17.07.2020] (in Russian)

Forbes (2020) Over 17.6 thousand Oralmans arrived in Kazakhstan in 2019. https://forbes.kz/ news/2020/01/23/newsid_217371 [Accessed on 17.07.2020] (in Russian)

Gazeta (2007) Come, but not to us. The State Program of return of compatriots is not interesting to the regions. https://web.archive.org/web/20071024201324/http://www.gzt.ru/society/2007/10/23/220035. html [Accessed on 17.07.2020] (in Russian)

Hess Ch, Green S (2016) Introduction: The changing politics and policies of migration in Germany. German Politics 25 (3): 315-328. https://doi.org/10.1080/09644008.2016.1172065. [Accessed on 17.07.2020]

Inbusiness.kz (2020) Kazakhstan reduced the quota of acceptance of Oralmans in 2020. https://inbusiness.kz/ru/last/kazahstan-sokratil-kvotu-priema-oralmanov-v-2020-godu. [Accessed on 17.07.2020] (in Russian)

IOM (2019) Glossary on Migration. https://publications.iom.int/system/files/pdf/iml_34_glossary. pdf. [Accessed on 17.07.2020]

Kommersant (2019) Russians do not come. The Program of resettlement of compatriots has been in place for 13 years. Is there an effect? https://www.kommersant.ru/doc/4031954 [Accessed on 17.07.2020] (in Russian)

Kovalev MP (2009) Repatriation as a type of migration: methodological problems of research. Vestnik Tomskogo gosudarstvennogo universiteta [Bulletin of Tomsk State University] (327): 42-44. http:// sun.tsu.ru/mminfo/000063105/327/image/327-042.pdf [Accessed on 17.07.2020] (in Russian)

Krasinets ES (2016) Resettlement programs in solving regional socio-demographic problems of modern Russia. In: Rise of the regional economy - strategic priority for Russia. VI International scientific and practical conference "Abalkin readings", Moscow (Russia), May 2016, 126-136. (in Russian) 
Maltz D, (2019) How many returnees from Russia are not Jewish? https://stmegi.com/opinions/posts/76582/skolko-zhe-repatriantov-iz-rossii-ne-yavlyayutsya-evreyami/ [Accessed on 17.07.2020] (in Russian)

MIA of Russia (2017) Monitoring of the implementation of the State Program of assistance to voluntary resettlement to the Russian Federation of compatriots living abroad, in the territories of entities Russian Federation in the fourth quarter of 2017. https://файлы.мвд.pф/Qd6x3wBL. [Accessed on 17.07.2020] (in Russian)

MIA of Russia (2018) Monitoring of the implementation of the State Program of assistance to voluntary resettlement to the Russian Federation of compatriots living abroad, in Russian regions in the fourth quarter of 2018. https://media.mvd.ru/files/application/1506369. [Accessed on 17.07.2020] (in Russian)

MIA of Russia (2019a) Monitoring of the implementation of the State Program of assistance to voluntary resettlement to the Russian Federation of compatriots living abroad, in the territories of entities Russian Federation in the fourth quarter of 2019. https://media.mvd.ru/files/application/1755550. [Accessed on 17.07.2020] (in Russian)

MIA of Russia (2020a) Monitoring of the implementation of the State Program of assistance to voluntary resettlement to the Russian Federation of compatriots living abroad, in the territories of entities Russian Federation in the first quarter of 2020. https://media.mvd.ru/files/application/1845932. [Accessed on 17.07.2020] (in Russian)

MIA of Russia (2019b) Official information package on the State Program of assistance to voluntary resettlement to the Russian Federation of compatriots living abroad: compendium of information materials. https://media.mvd.ru/files/application/1623373 [Accessed on 17.07.2020] (in Russian)

MIA of Russia (2019c) Summary of main indicators on the migration situation in the Russian Federation for January-December 2018. https://xn--blaew.xn--plai/Deljatelnost/statistics/migracionnaya/item/15850787/. [Accessed on 17.07.2020] (in Russian)

MIA of Russia (2020b). Main indicators on the migration situation in the Russian Federation for January-December 2019. https://xn--blaew.xn--plai/Deljatelnost/statistics/migracionnaya/ item/19364859/. [Accessed on 17.07.2020] (in Russian)

Nakhshoni K (2019) The Ministry of Internal Affairs again restated Russian-speaking returnees: over 60\% non-Jews. Vesti. Israel in Russian https://www.vesty.co.il/articles/0,7340,L-5648159,00.html [Accessed on 17.07.2020] (in Russian)

Newsland (2009) CIS is to blame for the failure of resettlement of compatriots. http://newsland.com/ user/4296648029/content/v-provale-pereseleniia-sootechestvennikov-vinovato-sng/3937587 [Accessed on 17.07.2020] (in Russian)

Nezavisimaya Gazeta (2018) The State Program for resettlement of compatriots is exactly repatriation. http://www.ng.ru/ideas/2018-11-21/5_7444_idei.html [Accessed on 17.07.2020] (in Russian)

Order of the Federal Migration Service (FMS of Russia) (2007) "On approval of the instruction on work with compatriots willing to voluntarily relocate to the Russian Federation within and under conditions of the State Program of assistance to voluntary resettlement to the Russian Federation of compatriots living abroad, at the office of the Federal Migration Service abroad” of 02.08.2007 № 166. https:// rg.ru/2007/08/21/sootechestvenniki-instrukcia-dok.html. [Accessed on 17.07.2020] (in Russian)

Order of the Ministry of Regional Development (2006) "On approval of the regulations on criteria for the attribution of Russian regions to categories of the territory of investiture by which the volume of state support provided to Russian regions participating in the State Program of assistance to voluntary resettlement to the Russian Federation of compatriots is determined” of 29.12. 2006 № 152. http://docs.cntd.ru/document/902025504. [Accessed on 17.07.2020] (in Russian)

Pension Fund of the Russian Federation (2019) Pension system of Russia in figures and facts. Annual report 2018. http://www.pfrf.ru/press_center/annual_report/. [Accessed on 17.07.2020] (in Russian) 
Report on results and main activities of the Federal Migration Service of Russia for 2008-2010. Section "2.2.1. Implementation of the State Program in the FMS of Russia". http://100-bal.ru/pravo/193263/ index.html?page $=13$ [Accessed on 17.07.2020] (in Russian)

Resolution of Magadan Oblast administration "On approval of the state Program of Magadan Oblast 'Labour resources of Magadan Oblast”" of 31.10.2013 № 1051-pa. http:// docs.cntd.ru/document/460206766. [Accessed on 17.07.2020] (in Russian)

Resolution of the administration of Vladimir Oblast "On amendments to the annex to the resolution of the administration of Vladimir Oblast of 23.09.2016 № 840” of 28.03.2018 № 238. http://publication. pravo.gov.ru/File/GetFile/3300201804040004?type=pdf. [Accessed on 17.07.2020] (in Russian)

Resolution of the Government of the Republic of Kazakhstan "On approval of the 'Nurly Kosh' Program 2009-2011” of 02.12.2008 № 1126. https://www.zakon.kz/141171-postanovlenie-pravitelstva-respubliki.html. [Accessed on 17.07.2020] (in Russian)

Resolution of the Government of the Republic of Kazakhstan "On approval of the concept of migration policy of the Republic of Kazakhstan for 2017-2021 and the Action plan for implementation of the migration policy concept of the Republic of Kazakhstan for 2017-2021” of 29.09.2017 № 602 https://online.zakon.kz/m/Document/?doc_id=38732493. [Accessed on 17.07.2020] (in Russian)

Resolution of the Government of the Russian Federation (2007a) "On the procedure for payment to participants of the State Program for assistance to voluntary resettlement to the Russian Federation of compatriots living abroad and members of their families of a monthly allowance in the absence of income from work, business and other activities” of 15.01.2007 № 8 http://docs.cntd.ru/document/902022762. [Accessed on 17.07.2020] (in Russian)

Resolution of the Government of the Russian Federation (2007b) "On approval of rules for payment to participants of the State Program of assistance to voluntary resettlement to the Russian Federation of compatriots living abroad, compensation for the expenses of moving to the future place of residence" of 10.03.2007 № 150 http://docs.cntd.ru/document/902031720. [Accessed on 17.07.2020] (in Russian)

Resolution of the Government of the Russian Federation (2008) "On approval of rules for payment to participants of the State Program of assistance to voluntary resettlement to the Russian Federation of compatriots living abroad and members of their families of compensation at the expense of the federal budget for payment of state duty for documents defining the legal status of immigrants in the territory of the Russian Federation” of 25.09.2008 № 715 http://base.garant.ru/12162504/. [Accessed on 17.07.2020] (in Russian)

Resolution of the Government of the Russian Federation (2013) "On the procedure for the implementation of payment of the settlement allowance for the participants of the State Program of assistance to voluntary resettlement to the Russian Federation of compatriots living abroad and their family members” of 27.03.2013 № 270. http://base.garant.ru/70348450/. [Accessed on 17.07.2020] (in Russian)

Rossiyskaya Gazeta (2006) Decree of the President of the Russian Federation of June 22, 2006 № 637 "On assistance to voluntary resettlement to the Russian Federation of compatriots living abroad" https://rg.ru/2006/06/28/ukaz-pereselenie.html [Accessed on 17.07.2020] (in Russian)

Rossotrudnichestvo (2019) The description of the State Program of assistance to voluntary resettlement to the Russian Federation of compatriots living abroad. http://rs.gov.ru/ru/pages/9 [Accessed on 17.07.2020] (in Russian)

Ryazantsev SV, Grebenyuk AA (2008) Potential of the return migration to Russia from the CIS and Baltic countries. Narodonaselenie [Population] (2): 104-111. https://elibrary.ru/item.asp?id=11520358 [Accessed on 17.07.2020] (in Russian)

Shurshalova ES (2019) Voluntary repatriation: legal support and implementation issues. Pravovaya politika i pravovaya zhizn' [Legal policy and legal life] (1): 71-77. https://elibrary.ru/item.asp?id=37108447 [Accessed on 17.07.2020] (in Russian) 
Sputnik (2019) The Lithuanian Seimas approved the law on the resettlement of Lithuanians from crisis zones. https://lt.sputniknews.ru/society/20190427/8883414/Seym-Lithuania-utverdil-zakon-o-pereselenii-litovtsev-iz-zon-krizisa.html [Accessed on 17.07.2020] (in Russian)

Stein B (1997) Refugee repatriation, return and refoulement during conflict. US Agency for international development. Promoting democracy, human rights, and reintegration in post-conflict societies. http://citeseerx.ist.psu.edu/viewdoc/download?doi=10.1.1.500.8396\&rep=rep1\&type=pdf. [Accessed on 17.07.2020]

Strusov IA, Yukhachyov SP (2016) Points-based system of selection - the instrument of increase of efficiency of realization of the measures of the State Program on assistance to voluntary resettlement to the Russian Federation of the compatriots living abroad, in the territory of the Tambov region. Sotsial'no-ehkonomicheskie yavleniya i protsessy [Socio-economic phenomena and processes] 11 (3): 112-116. https://elibrary.ru/item.asp?id=25920039 [Accessed on 17.07.2020] (in Russian)

Sultanmuratov N (2017) Repatriation policy: big dilemma for Kazakhstan? Center of Asia 4 (110) https://www.asiakz.com/politika-repatriacii-bolshaya-dilemma-dlya-kazahstana [Accessed on 17.07.2020] (in Russian)

Tolts M (2019) A half century of Jewish emigration from the former Soviet Union: Demographic aspects. https://doi.org/10.13140/RG.2.2.18095.36004 [Accessed on 17.07.2020]

Treaty on the Eurasian Economic Union (2014) http://www.consultant.ru/document/cons_doc_ LAW_163855/ [Accessed on 17.07.2020] (in Russian)

Vishnevsky A (2013) Introductory article. New role of migration in the demographic development of Russia. In: Zayonchkovskaya JA (Ed) Migration in Russia 2000-2012. Spetskniga, Moscow, 99-100. (in Russian)

Vykhovanets O, Zhuravsky A. (2013) Return of Compatriots. https://russiancouncil.ru/analytics-and-comments/analytics/vozvrashchenie-sootechestvennikov/ [Accessed on 17.07.2020] (in Russian)

Yumaguzin VV, Vinnik MV (2019) How many migrants are necessary for ensuring natural increase in russia till 2024? In: Ryazantsev SV, Rostovskaya T (Eds) National demographic priorities: approaches and measures of implementation. 5 (4). Econ-Inform, Moscow, 549-552. https://publications.hse.ru/chapters/277418627 [Accessed on 17.07.2020] (in Russian)

Zayonchkovskaya Zh (2007) Why Russia needs immigration policy. In: Zayonchkovskaya J, Molodikova I, Mucomel V (Eds) Methodology and methods of studying migration processes. Interdisciplinary tutorial. The Center for migration studies with the assistance of the Higher education support program of the Open society institute (HESP OSI) and the UNESCO Bureau in Moscow, Moscow, 114-141. (in Russian)

Zeveleva OI (2013) Repatriation and national identity: experience of Russia and Germany. Chapter 17. In: Russia and Germany in the space of European communications. Publishing house of Tyumen State University, Tyumen, 246-263. URL: https://publications.hse.ru/mirror/pubs/share/folder/anjgrdwr0b/direct/147009964. [Accessed on 17.07.2020] (in Russian)

Zeveleva OI (2014) Migration policy and collective identity: the case of the Russian-Germans in Germany. Polis. Politicheskie issledovaniya [Polis. Political studies] (6): 114-126. https://doi. org/10.17976/jpps/2014.06.09. [Accessed on 17.07.2020] (in Russian)

\section{Information about the authors}

- Ekaterina Vsevolodovna Donets, Candidate of Economics, independent researcher. E-mail: donets-e@mail.ru

- Olga Sergeevna Chudinovskikh, Candidate of Economics, Head of the Laboratory of economics of population and demography, Faculty of Economics of Lomonosov Moscow State University. E-mail: olga@econ.msu.ru 